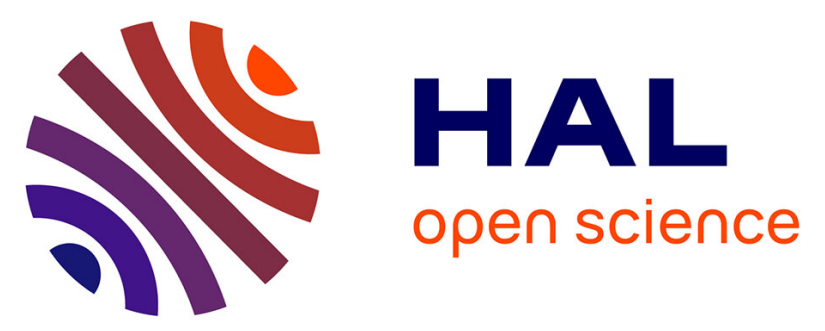

\title{
Immunohistochemistry compared to cytosol assays for determination of estrogen receptor and prediction of the long-term effect of adjuvant tamoxifen
}

Mahmoud R. Khoshnoud, Britta Löfdahl, Helena Fohlin, Tommy Fornander, Olle Stål, Lambert Skoog, Jonas Bergh, Bo Nordenskjöld

\section{To cite this version:}

Mahmoud R. Khoshnoud, Britta Löfdahl, Helena Fohlin, Tommy Fornander, Olle Stål, et al.. Immunohistochemistry compared to cytosol assays for determination of estrogen receptor and prediction of the long-term effect of adjuvant tamoxifen. Breast Cancer Research and Treatment, 2010, 126 (2), pp.421-430. 10.1007/s10549-010-1202-7 . hal-00586983

\section{HAL Id: hal-00586983 https://hal.science/hal-00586983}

Submitted on 19 Apr 2011

HAL is a multi-disciplinary open access archive for the deposit and dissemination of scientific research documents, whether they are published or not. The documents may come from teaching and research institutions in France or abroad, or from public or private research centers.
L'archive ouverte pluridisciplinaire HAL, est destinée au dépôt et à la diffusion de documents scientifiques de niveau recherche, publiés ou non, émanant des établissements d'enseignement et de recherche français ou étrangers, des laboratoires publics ou privés. 


\title{
Immunohistochemistry compared to cytosol assays for determination of Estrogen receptor and prediction of the long term effect of adjuvant tamoxifen
}

\author{
Mahmoud R. Khoshnoud ${ }^{1}$, Britta Löfdahl ${ }^{2}$, Helena Fohlin $^{3}$, Tommy Fornander ${ }^{1}$, Olle Stål ${ }^{4}$, Lambert Skoog ${ }^{5}$, \\ Jonas Bergh $^{6,7}$, Bo Nordenskjöld ${ }^{4}$ \\ 1-Department of Oncology-Pathology, Karolinska Institute, Stockholm, Sweden 2-Department of pathology, \\ Uppsala University Hospital.3-Oncology centre, Linköping University Hospital.4- Department of clinical and \\ experimental Medicine/ oncology, Faculty of Health sciences, Linköping University, Linköping, Sweden 5- \\ Department of pathology, Karolinska University Hospital. 6-Cancer Center Karolinska. 7- Medical Breast Unit, \\ Christie Hospital, Paterson Institute/ Manchester University
}

Running title: validation of ER

Keywords: breast cancer, estrogen receptor, tamoxifen, cytosol, Immunohistochemical

Corresponding author: Mahmoud R. Khoshnoud, Department of Oncology, Karolinska University Hospital, Södersjukhuset, Sjukhusbacken 10, 11883 Stockholm, Sweden. Tel:46(8)6164381,fax:46(8) 6163884 mail:Mahmoud.khoshnoud@karolinska.se 


\begin{abstract}
Purpose

To compare immunohistochemistry (IHC) and cytosol based assays for determination of estrogen receptor (ER) and prediction of response to adjuvant tamoxifen treatment in postmenopausal women with early stage invasive breast cancer.

Patients and methods

The Stockholm Breast Cancer Study Group conducted a randomized trial during 1976 through 1990 comparing adjuvant tamoxifen versus control. The patients were stratified according to tumor size and lymph node status in high risk and low risk groups. In this study we evaluated 683 patients with "low risk" breast cancer (size $\leq 30$ mm, lymph node-negative) for whom ER status had been determined by both the cytosol assays and immunohistochemistry at one pathology laboratory. The median follow up was 17 years.

Result

Six hundred eighty three patients had tumors with ER determined by both methods, 536 (78.5\%) were ERpositive by cytosol assays using the cut off level at $\geq 0.05 \mathrm{fmol} / \mu \mathrm{g}$ DNA and 539 patients were ER-positive (79\%) by IHC using the cut off level at $\geq 10$ percent cell stained. Thirty-nine tumors (5.7\%) were ER-positive by cytosol but not by IHC, whereas the opposite pattern was found for 42 cases $(6.1 \%)$. Only seven tumors had stained cells between zero and nine percent by IHC. The concordance between IHC and cytosol assays was high (88\%). The kappa statistic was 0.65 , 95\%CI 0.58 to 0.72 . Among patients classified as ER-negative no therapeutic benefit from tamoxifen was observed. Among patients with ER- expressing tumors tamoxifen resulted in significantly better recurrence free survival irrespective of the method (IHC: $\mathrm{HR}, 0.53, \mathrm{P}<0.001$; cytosol: HR, 0.53, P<0.001). The effect on overall survival was not statistically significant probably due to the limited sample size.
\end{abstract}

Conclusion

Both IHC and cytosol assay accurately predict long-term response to adjuvant tamoxifen. 


\section{Introduction}

Estrogen (ER) and progesterone (PGR) receptors are well-established predictors for the effect of endocrine treatment in both primary and metastatic breast cancer [1-3]. The prognostic value for these receptors still is a matter of debate. Earlier studies reported a more favourable prognosis for patients with ER-positive tumors [4-6], while later studies showed that the early advantage for ER-positive breast cancers was not sustained over time [7-9]. Furthermore, we previously reported a frail prognostic value for ER [10] and that the better outcome for patients with ER-positive tumors is obvious only for patients who received endocrine therapy.

Before approximately 1990 determination of ER and PGR was based on biochemical methods, which measured the level of receptors in cytosol initially by a ligand binding assay, later replaced by monoclonal antibody based assays. Cytosol assays were time consuming, expensive and required fresh tissue and measured receptor content in both cancer cells and normal cells in the tumor tissue. However an advantage of the cytosol method was that it offered quantitation of the receptor levels. On the other hand IHC has many advantages compared with cytosol methods. It is cheaper, faster and does not require fresh material. Furthermore, it is possible to perform on small amounts tumor cells, and ER and PGR are measured in cancer cells only.

A high concordance between biochemical and immunochemical methods was reported in several studies [11-14]. Immunohistochemistry and cytosol assays were shown to yield similar predictive and prognostic information [15-17], but the majority of these studies had a short follow-up and many patients received a range of therapies. To our knowledge there are only few studies comparing these methods in an adjuvant randomized setting [1719].

The aim of this study was to compare the predictive value of ER measured in the cytosol of the unfixed tumor with ER status obtained by an immunohistochemical assay performed on archival tissue. For this, we used tumors from a well-defined randomized clinical adjuvant trial conducted by Stockholm Breast cancer Group where high quality data on long-term follow- up is available. We furthermore investigated the extent to which the methods of assessing the hormone receptors may affect trial conclusions. 


\section{Material and methods}

Study design:

Patients with an operable invasive breast cancer entered in a controlled clinical study of adjuvant endocrine therapy conducted by the Stockholm Breast Cancer Study Group, the Stockholm Adjuvant Tamoxifen Trial (STO-3). The trial was approved by the local ethical committee and the details of this study were described previously [20]. Postmenopausal women at the age of 70 or less with invasive breast cancer were randomly given tamoxifen postoperatively at a dose of $40 \mathrm{mg}$ per day compared with no adjuvant endocrine therapy. A woman was considered postmenopausal if more than 6 months had emerged since her last menstrual period. During November 1976 through June 1990, a total of 2,738 patients entered the trial. The trial included patients irrespective of hormone receptor content but prospectively collected data on ER status were available in 2012 (85\%) patients. ER-status was absent mainly in patients with small tumors from which all tissue was used to verify the histophatological diagnosis of breast cancer.

Before randomization the patients were stratified according to stage of disease and primary therapy. 1780 patients (65\%) with no lymph node metastases and a tumor diameter of $30 \mathrm{~mm}$ or less (established by histological examination) were classified as "low risk". In this group, 432 patients were treated with breast conserving surgery including axillary dissection plus radiation to the breast (50 Gy/ 5 weeks). The remaining 1,348 patients had a modified radical mastectomy.

Present study population:

For the purpose of this study, we selected the 1,780 "low risk" patients because they received no adjuvant chemotherapy known to affect recurrence free and overall survival. These patients were randomized between no systemic therapies versus tamoxifen in contrast to a high-risk group also given chemotherapy. The data on the estrogen receptor status was known for 1183 (66.5\%) which was originally determined by cytosol assays. Tumor material was available for 1,001 of these 1,780 patients. From 912 of these 1001 tumors, tissue microarray (TMA) could be created and sections stained for estrogen receptor by IHC, for the 89 remaining patients the archival material was of poor quality or not representative ( e.g cancer in situ, normal cells, connective tissue ). 790 of 912 tumors were technically evaluable by IHC and the remaining was difficult to interpret because of too few tumor cells. Data on ER receptor by cytosol for 777 of 912 patients were available. Re-evaluation was performed on 683 patients for whom the ER status was known by both cytosol and IHC (Figure1).

Follow -up strategies:

Clinical visits took place once every 3 months during the first 2 years, every 6 months during 2-5 years and yearly thereafter. These visits routinely included a physical examination and an annual mammogram. Chest Xray, blood sample, bone scans, etc were performed if clinical symptoms and signs indicated a probable relapse. Disease recurrence was confirmed when possible by biopsy. However, bone and visceral metastases were sometime established on unequivocal radiological evidence. Recurrence was dated from the first evidence of relapse based on physical, histological, or imaging data. After recurrence, treatment was decided individually. 
The current results were based on follow-up until December 31, 2005. The proportion of patients lost to followup before this date was $<1 \%$.

\section{ER determination:}

The ER cytosol assays were performed in one laboratory in Stockholm, a participant in the Swedish national wide quality control programme for hormone receptor laboratories sponsored by the Swedish Cancer Society. Representative tumor sample was collected immediately after surgery and transported to the laboratory in saline according to the guidelines in the study protocol. The samples were frozen and stored at $-80 \mathrm{C}$ for 2 weeks or less. After thawing, the content of ER was determined using isoelectric focusing (IF) on polyacrylamide gel as previously described [21, 22]. This technique was used for samples assayed before 1988. After 1988 an enzyme immunoassay (ElA) was used. Studies have showed that results with these techniques correlate well with those obtained using methods based on ultra centrifugation, dextran-coated charcoal, and monoclonal antibodies [2124]. The receptor values in this study were normalized to DNA content as measured by Burton to avoid the influence of the large variations in extracellular protein [25]. A tumor with a receptor content of $\geq 0.05 \mathrm{fmol} / \mu \mathrm{g}$ DNA was classified as ER positive. This cut-off point was chosen since a previous analysis indicated that it distinguished between patients who benefited from adjuvant tamoxifen and those who did not.

\section{Immunohistochemistry:}

The immunohistochemical staining was performed using the Ventana automatic BenchMark machine (Ventana Medical Systems, S.A, lllkirch, Cedex, France). A rabbit monoclonal ER antibody (Sp1 250) was used. Antigen retrieval and staining procedure were performed according to the Ventana instructions.

\section{Statistics:}

Overall (OS) and recurrence-free survival (RFS) was estimated by the Kaplan-Meier method. The end-point in calculations of RFS was loco-regional recurrence, distant recurrence or death due to breast cancer. Hazard ratios (HR) were estimated using the Cox's proportional hazards model. The pattern of the treatment effect of tamoxifen for different ER values of both cytosol and IHC was studied. For this purpose, Subpopulation Treatment Effect Pattern Plots (STEPP) analysis [26] was performed. The method used was the tail-oriented version with $g_{=} 7$, generating thirteen overlapping subgroups (six for decreasing ER values, one for all patients and six for increasing ER values). The STEPP plots show the tamoxifen effect estimated in each of these created subgroups.

The sensitivity and specificity corresponding to different choices of cut-off for ER cytosol values compared to ER determined by IHC were explored using a Receiver Operating Characteristic curve (ROC). For this analysis the cut-off for ER positivity by IHC was set to $10 \%$ stained cells. The software used for the statistical analysis was Stata/SE 10.0 


\section{Results}

\section{Clinical characteristics:}

Among 1780 postmenopausal patients with "low-risk" invasive breast cancer randomly assigned to treatment in the STO-3 trial, 1183 patients (66. 5\%) had ER-positive disease, 296 (16.6\%) had ER-negative disease and the remaining 301 patients $(17 \%)$ had unknown estrogen receptor status. Median follow-up was 17 years. The tamoxifen and control groups were well balanced regarding clinical characteristics (Table 1).

Among 912 women with tumor material available in tissue microarrays, ER had been determined in the cytosol in 777 cases (85\%) and by IHC in 790 cases (86.5\%). ER was determined by both methods in 683 tumors (75\%) described below. The clinical characteristics of patients in this study and patients in "low-risk group" of the STO-3 trial were comparable (table 1), However in this study, there were fewer patients with tumor size less than $10 \mathrm{~mm}$ than the low-risk group (22\% and $31 \%$ respectively) and more patients with tumor size 11-30 mm (76\% and 65\% respectively). The other dissimilarity was that all patients in this cohort have a known ER status but in the "low-risk" population 17\% had unknown ER status.

Concordance between the methods:

Six hundred eighty three patients had tumors with known ER status by both methods, 536 (78.5\%) were ERpositive by cytosol assays (ER $\geq 0.05 \mathrm{fmol} / \mu \mathrm{g}$ DNA) and 539 ER-positive (79\%) by IHC (ER $\geq 10 \%)$. Thirty nine (5.7\%) had ER-positive cytosol assays but negative IHC, whereas the opposite pattern was found in 42 cases $(6.1 \%)$ (Table 2). ER status from cytosol assays indicated that 147 (21.5\%) of 683 tumours were ER-negative. When the ER status of these ER-negative tumors by the cytosol assays was determined by IHC, 42 (28.5\%) were ER positive. Of 536 tumors classified as ER-positive by the cytosol assays, 39(7\%) were classified as ER negative by IHC. The concordance between the two assays was high $(88 \%)$. The kappa statistic for concordance was 0.65 , (CI 0.58 to 0.72 ) when using two categories (ER-positive and ER- negative) for each method. Only seven tumors were classified into the low category by IHC (1\%-9\% of cells stained).

ER status and clinical outcomes:

Recurrence free survival, overall survival and breast cancer specific survival in the tamoxifen and control groups were correlated to hormone receptor levels. With cytosol data we compared ER-negative cases (ERnegative $<0.05 \mathrm{fmol} / \mu \mathrm{g}$ DNA) and ER-positive ones ( $\geq 0.05 \mathrm{fmol} / \mu \mathrm{g}$ DNA) and also compared ER-negative cases with cases with intermediate levels $(\mathrm{ER}+0.05 \leq \mathrm{ER}<1 \mathrm{fmol} / \mu \mathrm{g}$ DNA), and high levels (ER++, ER $\geq 1 \mathrm{fmol} / \mu \mathrm{g}$ DNA). Similarly, we compared patients grouped by IHC data, ER-negative ( $<10 \%$ stained cells) or ER- positive ( $\geq 10 \%$ cells stained). We also compared the cases with no staining and cases with $10-85 \%$ cells stained and a group with more than $85 \%$ stained cells. Both assays yielded ER-data with strong correlation to treatment benefit. Patients with ER-negative tumors showed no benefit from treatment with tamoxifen neither in term of recurrence free survival nor overall survival regardless with which assay the ER status was determined (e.g., for the comparison tamoxifen versus no tamoxifen: (ER-negative cytosol $\mathrm{HR} 0.87,95 \% \mathrm{Cl}=0.48$ to 1.60 ; ERnegative $\mathrm{IHC} \mathrm{HR}=0.74,95 \% \mathrm{Cl}=0,43$ to 1.28 ; ER- absent ( $0 \%$ stained cells) by $\mathrm{IHC}, \mathrm{HR}=0.73,95 \% \mathrm{Cl} 0.42$ to 1.28) (figure2). Patients with ER-positive breast cancer allocated to tamoxifen showed statistically significant 
better recurrence free survival. Both assay methods defined ER positive groups with similar estimated hazard ratios and 95\% confidence intervals for tamoxifen benefit ( $\mathrm{ER}$ cytosol-positive $\mathrm{HR} 0.51,95 \% \mathrm{Cl} 0.36$ to 0.73 , $\mathrm{P}<0.001$; ER $\mathrm{IHC}>0 \%_{\text {present } \mathrm{HR}} 0.54,95 \% \mathrm{Cl} 0.38$ to $0.75, \mathrm{P}<0.001$; $\mathrm{ER}_{\mathrm{IHC}>10 \%}$-positive $\mathrm{HR} 0.53,95 \% \mathrm{Cl} 0.37$ to $0.74, \mathrm{P}<0.001$ ) (figure 3). Overall mortality was slightly reduced by tamoxifen treatment but the differences were not statistically significant, likely due to a relatively low power. However the treatment benefit with tamoxifen appeared to be marginally greater among those classified as ER-positive by cytosol assays compared to those classified with IHC assay (HR 0.80 and 0.87 respectively)(Figure 3). For more detailed correlation of treatment benefit to ER levels measured by IHC and cytosol assays we divided the patients in three groups, (ER $<0.05 \mathrm{fmol} / \mu \mathrm{g}$ DNA/147 tumors (21.5\%), $0.05 \mathrm{fmol} / \mu \mathrm{g}$ DNA $\leq \mathrm{ER}<1.0 \mathrm{fmol} / \mu \mathrm{g}$ DNA/264 tumours (38.7\%) and $\mathrm{ER} \geq 1.0 \mathrm{fmol} / \mu \mathrm{g}$ DNA/ 272 tumours (39.8\%) measured by cytosol assays) and (ER $<10 \% / 144$ tumours (21\%), $10 \% \leq \mathrm{ER}<85 \% / 260$ tumours (38\%) and $\mathrm{ER} \geq 85 \% / 279$ tumors $(41 \%)$ by IHC). The analyses revealed that there was no benefit of tamoxifen among patients with ER-negative by any assays. Among patients with ERpositivity defined by IHC, the benefit from tamoxifen appeared to be unrelated to the percentage stained cells, but in the group with ER-positivity measured by cytosol assays the benefit from tamoxifen treatment appeared to be related to the ER concentration and an increased benefit with ER ( $\geq 1.0 \mathrm{fmol} / \mu \mathrm{g}$ DNA (data not shown).

To investigate the trends in tamoxifen treatment effect differences across the continuum of ER status, we performed STEPP (Subpopulation Treatment Effect Pattern Plot) analyses (fig 4). The STEPP curves show the effect of tamoxifen for overlapping subgroups with different median ER values by cytosol (Fig 4a) and by IHC (Fig 4b). The STEPP curve for ER determined by IHC does not start with a zero point on log relative hazard indicating some effect of tamoxifen in patients with low ER value by IHC. The Kaplan-Meier curve of recurrence free survival for tamoxifen effect for $\mathrm{ER}_{\mathrm{IHC}}$-negative(ER $<10 \%$ ) shows as well the same trend (FIG 2b). Likewise, the STEPP curve of IHC has a shallow slip in comparison to the STEPP curve of cytosol that shows an obvious trend in tamoxifen effect with greater effect in subpopulation with higher median ER content. However, based on these analyses we were unable to identify an abrupt changing in tamoxifen effect separating the subpopulations without effect from the subpopulations with effect from tamoxifen. Further statistical analyses by ROC curves and testing different cutoff levels for cytosol $(0.01 \mathrm{fmol} / \mu \mathrm{DNA}$ and $0.05 \mathrm{fmol} / \mu \mathrm{DNA})$ and IHC (1\%, 10\% and 20\%), to identify an optimal cutoff level for both assays were performed. However, the ROC curve which was created by choosing different cutoff level for ER cytosol values, compared to ER determined by IHC and if the cutoff level for considering ER to be positive by IHC was set to $10 \%$, the majority of tumors were correctly classified with a cutoff level for cytosol from 0.05-0.08 fmol/ $\mu$ DNA (between 88.1\%$88.4 \%$ with sensitivity $92.2 \%-90.7 \%$ and specificity $72.9 \%-79.9 \%$ respectively) (Fig 5a). The sensitivity and specificity corresponding to cutoff of $10 \%$ for ER determined by IHC compared to ER cytosol values and if the cutoff level for considering ER to be positive by cytosol was chosen $0.05 \mathrm{fmol} / \mu \mathrm{DNA}$, was 92.7 and 71.4 respectively and $88.1 \%$ of the tumors could be classified correctly (Fig 5b). It means that these two cutoff levels ( $10 \%$ by IHC and $0.05 \mathrm{fmol} / \mu \mathrm{DNA}$ ) are likely to be corresponding. We also conducted STEPP analysis for the two discordant groups: ER-positive by IHC but negative by cytosol (42 cases) and ER -negative by IHC but positive by cytosol (39 cases). The STEPP analyses of these two subgroups were not conclusive because of the small number of cases in each group (data not shown). On the other hand, the Kaplan-Meier plots of recurrencefree survival for tamoxifen effect in the discordant subgroup of ER-negative by cytosol(ER $<0.05 \mathrm{fmol} / \mu \mathrm{g}$ DNA) but positive by IHC (ER $\geq 10 \%)$ revealed similar effect for both tamoxifen and control group (Fig 6a). In contrast, 
the RFS in the discordant subgroup that was defined as ER-positive by cytosol (ER $\geq 0.05 \mathrm{fmol} / \mu \mathrm{g}$ DNA) but negative by IHC (ER<10\%), was greater in the tamoxifen group compared with the control group (Fig 6b). These results may indicate some more predictive ability of cytosol assays compared to IHC assay. However, this difference was not statistically significant and should be interpreted with caution because of the small number of patients in these groups. An analysis of events by period of follow-up showed that disease recurrences and total deaths were reduced among the tamoxifen treated patients mainly during the first 5 years (table 3 ). 
Discussion

The results from randomized studies in the 1970s changed the treatment of early stage breast cancer and established adjuvant tamoxifen therapy for ER-positive breast cancer [20, 27, 28]. However the importance of ER status as a predictor was not completely established until 1990[29]. The Stockholm adjuvant trial (STO-3) conducted by the Stockholm Breast Cancer Study Group was initiated in 1976. This study is one of the largest of adjuvant systemic therapy versus no adjuvant treatment. Inclusion was not based on hormone receptor status, although prospective data on receptor status was available for $85 \%$ of the patients. This has permitted evaluations of the treatment predictive ability of estrogen receptor. This report is based on the "low-risk" subpopulation of STO-3. The follow-up is long and few patients were lost to follow up.

Our data confirm that ER status measured by IHC is similar to that determined by the cytosol assays. The result showed no benefit from tamoxifen therapy for ER-negative patients regardless of assays performed. The pattern of the tamoxifen effect was similar for patients with absent staining cells (ER=0\%) compared to ER-negative $(\mathrm{ER}<10 \%)$. However only 7 tumors were stained between 1-9\%. Patients with ER-positivity defined by IHC or cytosol assay obtained similar benefit from tamoxifen treatment. In discordant groups the effect of tamoxifen in term of recurrence free survival showed dissimilarity. There were no differences between the tamoxifen group and the no tamoxifen group in $\mathrm{ER}_{\mathrm{cyt}}$-negative/ER $\mathrm{IHC}_{\mathrm{IHC}}$-positive, despite the majority of cytosol negative tumors showing high percent staining cells by IHC. In contrast, the tamoxifen group showed greater RFS compared to the no tamoxifen group in $\mathrm{ER}_{\mathrm{cyt}}$-positive/ER $\mathrm{IHC}_{\mathrm{IH}}$-negative discordant group. Whether this indicates a more sensitive predictive ability for cytosol assay or is a result by chance due to very small number of cases in each group, needs further validation from other studies. There may also be the possibility that the larger amount of fresh tissue used in the cytosol method positively impact the accuracy of this method. Although adjuvant tamoxifen was established based on ER measured by cytosol assays, we conclude that immunohistochemistry yields similar correlation to benefit of therapy. Two retrospective adjuvant studies conducted on archival tissue, one by Ferno et al [30] on 98 patients which received adjuvant tamoxifen, the other reported by Harvey et al [31] showed that estrogen receptor positivity determined by IHC significantly predicted improved disease free survival in patients receiving adjuvant tamoxifen therapy. To our knowledge only three other studies [17-19] used randomized clinical trial populations receiving adjuvant therapy but the cohort of patients were smaller, had shorter duration of follow up and mixed treatment arms [17, 18]. Regan at al re-evaluated and reported results from International Breast Cancer Study Group (IBCSG) trial VIII (pre-and perimenopausal patients) and trial IX (postmenopausal patients). The subset of patients in trial IX is similar to our cohort but randomization was between chemotherapy followed by tamoxifen versus tamoxifen. The median duration of follow-up was shorter and biochemical assays were performed at different local pathology laboratories [19]. However our results confirm results from these cohorts.

There is no general consensus concerning the estrogen receptor cut-off level separating endocrine responsive tumors from non-responsive one. In STO 3 trial a cut-off level of $0.05 \mathrm{fmol} / \mu \mathrm{g}$ DNA was used to distinguish receptor positive tumors from receptor-poor/receptor-negative tumors. Analysis of treatment benefit versus ER levels did not show any benefit for ER levels below $0.05 \mathrm{fmol} / \mu \mathrm{g}$ DNA [32]. In this study we used this cut-off 
level for cytosol assays. On the other hand, the IHC method has increasingly been used for determination of ER during recent decades and has been established as the routine assay for ER determination. Concerns associated with IHC assay which reduce its accuracy include variation in pre-analytical, analytical and post-analytical procedures, using different antibodies and diversities in interpretation and reporting results from IHC assays for determination of ER in breast cancer. To overcome this issue standardization of handling tissue, procedures, use of antibodies, interpretation and reporting result has been discussed and recently the American Society of Clinical Oncology (ASCO) and the college of American Pathologists (CAP) presented a guideline recommendations for IHC testing of ER and PR to improve accuracy of the method [33]. The second issue is to find a optimal cutoff level for IHC. For the immunohistochemical assay we used $10 \%$ stained cells as cut-off level that has been commonly used worldwide. Some recently data provide support for the use of cutoff level of $1 \%$ staining cells for ER as showing a better prognosis or some extent of endocrine effect [31, 33, 34]. However the $11^{\text {th }}$ St Gallen conference, defined endocrine responsiveness as the presence of any detectable estrogen receptor [35]. Our study could neither support nor reject these statements since only a small number of tumors had stained cells between zero and $25 \%$.

Some limitations of this cohort must be taken into account when interpreting the results. This study included only $38 \%$ of patients randomly allocated in the "low-risk" group. Although the clinical characteristics of patients in this study and those of the overall trial were comparable, the statistical power is reduced. The other limitation is the issue of cut point for Immunohistochemical assays. Only seven tumors had between 0 and 9 percent stained cells. We are thus unable to suggest an optimal cut point for the immunohistochemistry assay. Finally, a direct comparison of outcomes (e.g., recurrence free and overall survival) between patients whose tumours were estrogens receptor absent or negative by IHC and positive by cytosol assay with patients whose tumors were estrogen positive by IHC but negative by cytosol assay was not meaningful because of the small number of tumors with discordant data. 


\section{Conclusion}

We conclude that determination of estrogen receptor status by IHC could substitute cytosol assays with preserved ability to predict response to adjuvant tamoxifen treatment of early stage breast cancer. However, we observed $12 \%$ discordance in estrogen receptor status determined by IHC as compared to cytosol assays. In spite of this, estrogen receptor status determined by IHC confirmed randomized clinical trial results that were based on predicted response to tamoxifen therapy as well as estrogen receptor status measured by cytosol assay. 


\section{Acknowledgment}

This research was supported by grants from the Swedish Cancer Society and the Swedish Research Council to Olle Stål and Jonas Bergh and funds of Jonas Bergh’s research group at Radiumhemmet and the Stockholm County Council. 
1. Goldhirsch A, Wood WC, Gelber RD, Coates AS, Thurlimann B, Senn HJ: Meeting highlights: updated international expert consensus on the primary therapy of early breast cancer. J Clin Oncol 2003, 21(17):3357-3365.

2. McGuire: An update on estrogen and progestrone receptors in prognosis for primary and advanced breast cancer. In:Iacobelli S, et al, eds. New York: Raven Press; 1980.

3. Group EBCTC: Tamoxifen for early breast cancer: an overview of the randomised trials. Lancet 1998, 351(9114):1451-1467.

4. Crowe JP, Jr., Gordon NH, Hubay CA, Shenk RR, Zollinger RM, Brumberg DJ, McGuire WL, Shuck JM: Estrogen receptor determination and long term survival of patients with carcinoma of the breast. Surg Gynecol Obstet 1991, 173(4):273278.

5. Maynard PV, Blamey RW, Elston CW, Haybittle JL, Griffiths K: Estrogen receptor assay in primary breast cancer and early recurrence of the disease. Cancer Res 1978, 38(11 Pt 2):4292-4295.

6. Knight WA, Livingston RB, Gregory EJ, McGuire WL: Estrogen receptor as an independent prognostic factor for early recurrence in breast cancer. Cancer Res 1977, 37(12):4669-4671.

7. Aamdal S, Bormer O, Jorgensen O, Host H, Eliassen G, Kaalhus O, Pihl A: Estrogen receptors and long-term prognosis in breast cancer. Cancer 1984, 53(11):25252529.

8. Donegan WL: Prognostic factors. Stage and receptor status in breast cancer. Cancer 1992, 70(6 Suppl):1755-1764.

9. $\quad$ EBCTCG: Lancet 2005.

10. Khoshnoud MR, Fornander T, Johansson H, Rutqvist LE: Long-term pattern of disease recurrence among patients with early-stage breast cancer according to estrogen receptor status and use of adjuvant tamoxifen. Breast Cancer Res Treat 2008, 107(1):71-78.

11. Pertschuk LP, Kim DS, Nayer K, Feldman JG, Eisenberg KB, Carter AC, Rong ZT, Thelmo WL, Fleisher J, Greene GL: Immunocytochemical estrogen and progestin receptor assays in breast cancer with monoclonal antibodies. Histopathologic, demographic, and biochemical correlations and relationship to endocrine response and survival. Cancer 1990, 66(8):1663-1670.

12. Stierer M, Rosen H, Weber R, Hanak H, Auerbach L, Spona J, Tuchler H: Comparison of immunohistochemical and biochemical measurement of steroid receptors in primary breast cancer: evaluation of discordant findings. Breast Cancer Res Treat 1998, 50(2):125-134.

13. Zafrani B, Aubriot MH, Mouret E, De Cremoux P, De Rycke Y, Nicolas A, Boudou E, Vincent-Salomon A, Magdelenat H, Sastre-Garau X: High sensitivity and specificity of immunohistochemistry for the detection of hormone receptors in breast carcinoma: comparison with biochemical determination in a prospective study of 793 cases. Histopathology 2000, 37(6):536-545.

14. Chebil G, Bendahl PO, Idvall I, Ferno M: Comparison of immunohistochemical and biochemical assay of steroid receptors in primary breast cancer--clinical associations and reasons for discrepancies. Acta Oncol 2003, 42(7):719-725.

15. Beck T, Weikel W, Brumm C, Wilkens C, Pollow K, Knapstein PG: Immunohistochemical detection of hormone receptors in breast carcinomas (ERICA, PgR-ICA): prognostic usefulness and comparison with the biochemical radioactive-ligand-binding assay (DCC). Gynecol Oncol 1994, 53(2):220-227. 
16. Molino A, Micciolo R, Turazza M, Bonetti F, Piubello Q, Corgnati A, Sperotto L, Recaldin E, Spagnolli P, Manfrin E et al: Prognostic significance of estrogen receptors in $\mathbf{4 0 5}$ primary breast cancers: a comparison of immunohistochemical and biochemical methods. Breast Cancer Res Treat 1997, 45(3):241-249.

17. Fisher ER, Anderson S, Dean S, Dabbs D, Fisher B, Siderits R, Pritchard J, Pereira T, Geyer C, Wolmark N: Solving the dilemma of the immunohistochemical and other methods used for scoring estrogen receptor and progesterone receptor in patients with invasive breast carcinoma. Cancer 2005, 103(1):164-173.

18. Alberts SR, Ingle JN, Roche PR, Cha SS, Wold LE, Farr GH, Jr., Krook JE, Wieand HS: Comparison of estrogen receptor determinations by a biochemical ligandbinding assay and immunohistochemical staining with monoclonal antibody ER1D5 in females with lymph node positive breast carcinoma entered on two prospective clinical trials. Cancer 1996, 78(4):764-772.

19. Regan MM, Viale G, Mastropasqua MG, Maiorano E, Golouh R, Carbone A, Brown B, Suurkula M, Langman G, Mazzucchelli L et al: Re-evaluating adjuvant breast cancer trials: assessing hormone receptor status by immunohistochemical versus extraction assays. $J$ Natl Cancer Inst 2006, 98(21):1571-1581.

20. Rutqvist LE, Cedermark B, Glas U, Johansson H, Nordenskjold B, Skoog L, Somell A, Theve T, Friberg S, Askergren J: The Stockholm trial on adjuvant tamoxifen in early breast cancer. Correlation between estrogen receptor level and treatment effect. Breast Cancer Res Treat 1987, 10(3):255-266.

21. Wrange O, Nordenskjold B, Silfversward C, Granberg PO, Gustafsson JA: Isoelectric focusing of estradiol receptor protein from human mammary carcinoma - a comparison to sucrose gradient analysis. Eur J Cancer 1976, 12(9):695-700.

22. Wrange O, Nordenskjold B, Gustafsson JA: Cytosol estradiol receptor in human mammary carcinoma: an assay based on isoelectric focusing in polyacrylamide gel. Anal Biochem 1978, 85(2):461-475.

23. Ferno M, Borg A, Norgren A: A comparison of two steroid receptor assays in breast cancer: dextran coated charcoal and isoelectric focusing. Anticancer Res 1983, 3(4):243-246.

24. Ferno M, Borg A, Sellberg G: Enzyme immuno assay of the estrogen receptor in breast cancer biopsy samples. A comparison with isoelectric focusing. Acta Radiol Oncol 1986, 25(3):171-175.

25. Burton K: A study of the conditions and mechanism of the diphenylamine reaction for the colorimetric estimation of deoxyribonucleic acid. Biochem J 1956, 62(2):315-323.

26. Bonetti M, Gelber RD: A graphical method to assess treatment-covariate interactions using the Cox model on subsets of the data. Stat Med 2000, 19(19):2595-2609.

27. Baum M, Brinkley DM, Dossett JA, McPherson K, Patterson JS, Rubens RD, Smiddy FG, Stoll BA, Wilson A, Lea JC et al: Improved survival among patients treated with adjuvant tamoxifen after mastectomy for early breast cancer. Lancet 1983, 2(8347):450.

28. Stewart HJ, Prescott R: Adjuvant tamoxifen therapy and receptor levels. Lancet 1985, 1(8428):573.

29. Systemic treatment of early breast cancer by hormonal, cytotoxic, or immune therapy. 133 randomised trials involving 31,000 recurrences and 24,000 deaths among 75,000 women. Early Breast Cancer Trialists' Collaborative Group. Lancet 1992, 339(8785):71-85. 
30. Ferno M, Andersson C, Fallenius G, Idvall I: Oestrogen receptor analysis of paraffin sections and cytosol samples of primary breast cancer in relation to outcome after adjuvant tamoxifen treatment. The South Sweden Breast Cancer Group. Acta Oncol 1996, 35(1):17-22.

31. Harvey JM, Clark GM, Osborne CK, Allred DC: Estrogen receptor status by immunohistochemistry is superior to the ligand-binding assay for predicting response to adjuvant endocrine therapy in breast cancer. J Clin Oncol 1999, 17(5):1474-1481.

32. Rutqvist LE, Johansson H: Long-term follow-up of the randomized Stockholm trial on adjuvant tamoxifen among postmenopausal patients with early stage breast cancer. Acta Oncol 2007, 46(2):133-145.

33. Hammond ME, Hayes DF, Dowsett M, Allred DC, Hagerty KL, Badve S, Fitzgibbons PL, Francis G, Goldstein NS, Hayes M et al: American Society of Clinical Oncology/College Of American Pathologists guideline recommendations for immunohistochemical testing of estrogen and progesterone receptors in breast cancer. J Clin Oncol, 28(16):2784-2795.

34. Viale G, Regan MM, Maiorano E, Mastropasqua MG, Dell'Orto P, Rasmussen BB, Raffoul J, Neven P, Orosz Z, Braye S et al: Prognostic and predictive value of centrally reviewed expression of estrogen and progesterone receptors in a randomized trial comparing letrozole and tamoxifen adjuvant therapy for postmenopausal early breast cancer: BIG 1-98. J Clin Oncol 2007, 25(25):38463852.

35. Goldhirsch A, Ingle JN, Gelber RD, Coates AS, Thurlimann B, Senn HJ: Thresholds for therapies: highlights of the St Gallen International Expert Consensus on the primary therapy of early breast cancer 2009. Ann Oncol 2009, 20(8):1319-1329. 


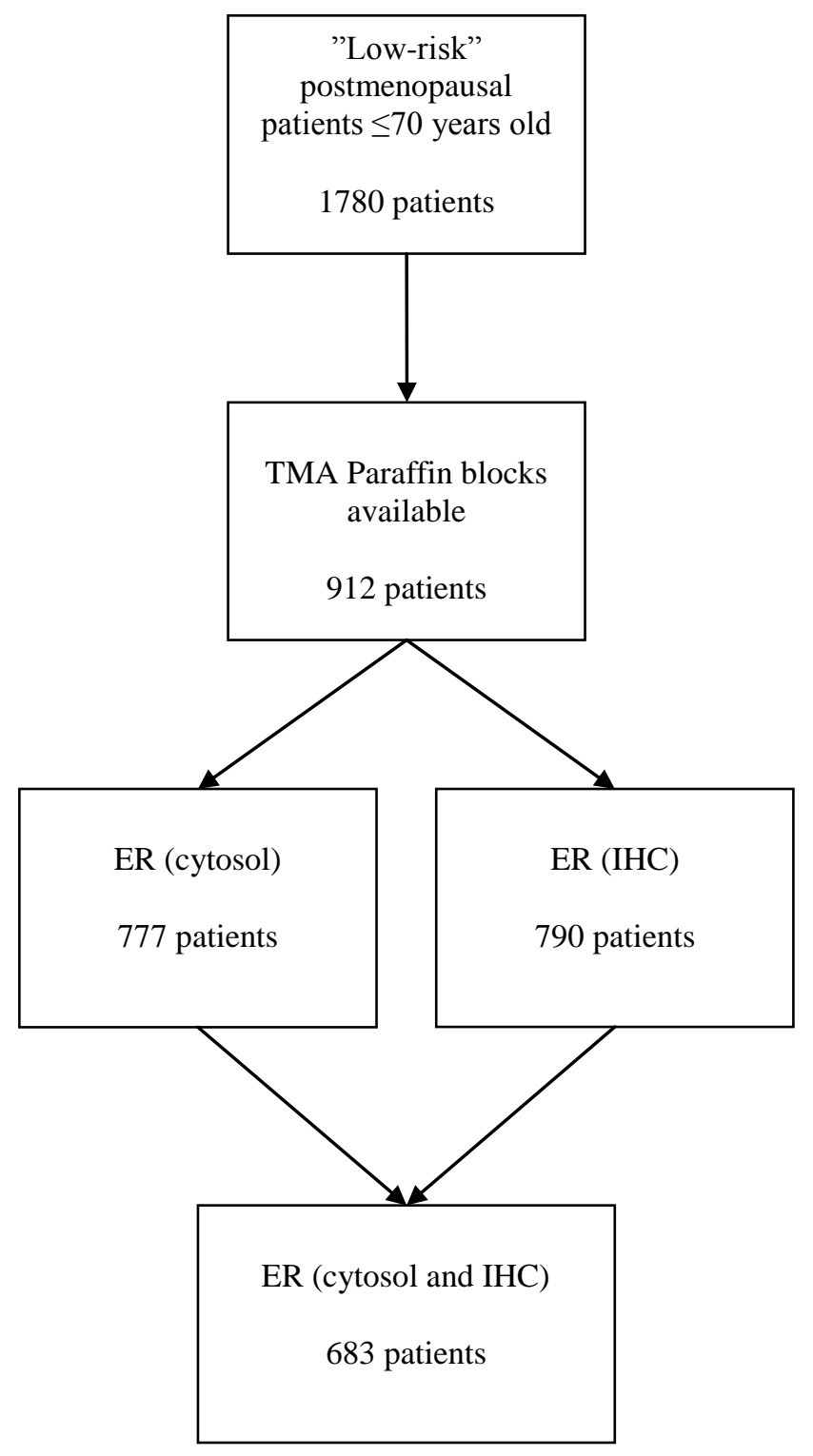

Figure 1; Summary of trial design 
Table 1; Distribution of patient characteristics by risk strata and allocated treatment in present study and entire "low-risk" population

\begin{tabular}{|c|c|c|c|c|}
\hline \multirow[t]{2}{*}{ Patient characteristics } & \multicolumn{2}{|c|}{ This study } & \multicolumn{2}{|c|}{ Low-risk group } \\
\hline & $\begin{array}{l}\begin{array}{l}\text { TAM+ } \\
(\mathrm{n}=350)\end{array}\end{array}$ & $\begin{array}{l}\text { TAM- }^{2} \\
(\mathrm{n}=333)\end{array}$ & $\begin{array}{l}\text { TAM+ } \\
(\mathrm{n}=886)\end{array}$ & $\begin{array}{l}\text { TAM- } \\
(\mathrm{n}=894)\end{array}$ \\
\hline \multicolumn{5}{|l|}{ RT } \\
\hline Yes & 19.7 & 19.8 & 24.0 & 24.5 \\
\hline No & 80.3 & 80.2 & 76.0 & 75.5 \\
\hline \multicolumn{5}{|l|}{ Age (years) } \\
\hline $40-49$ & 0.9 & 1.8 & 0.9 & 1.7 \\
\hline $50-59$ & 29.7 & 33.9 & 33.4 & 35.9 \\
\hline $60-69$ & 65.1 & 60.4 & 62.0 & 58.7 \\
\hline 70- & 4.3 & 3.9 & 3.7 & 3.7 \\
\hline \multicolumn{5}{|c|}{ Histopathological tumor size (mm) } \\
\hline$<10$ & 21.1 & 23.1 & 31.6 & 30.5 \\
\hline $11-20$ & 54.6 & 52.9 & 46.5 & 47.9 \\
\hline $21-30$ & 22.9 & 23.1 & 18.5 & 17.1 \\
\hline$>30$ & 0.0 & 0.3 & 0.1 & 0.6 \\
\hline Unavailable & 1.4 & 0.6 & 3.3 & 3.9 \\
\hline \multicolumn{5}{|c|}{ Histopathological nodal involvement } \\
\hline No & 99.7 & 99.7 & 99.1 & 98.2 \\
\hline N1-3 & 0.0 & 0.3 & 0.1 & 0.8 \\
\hline $\mathrm{N} 4+$ & 0.0 & 0.0 & 0.1 & 0.0 \\
\hline Unavailable & 0.3 & 0.0 & 0.7 & 1.0 \\
\hline \multicolumn{5}{|c|}{ Estrogen receptor status (IHC) } \\
\hline Positive & 79.4 & 78.4 & n. $a^{5}$ & n. $a^{5}$ \\
\hline Negative & 20.6 & 21.6 & n. $a^{5}$ & n..$^{5}$ \\
\hline \multicolumn{5}{|c|}{ Estrogen receptor status (cytosol) } \\
\hline Positive $^{3}$ & 80.0 & 76.9 & 67.2 & 65.8 \\
\hline Negative $^{4}$ & 20.0 & 23.1 & 16.0 & 17.2 \\
\hline Unavailable & & & 16.8 & 17.0 \\
\hline
\end{tabular}

1-adjuvant tamoxifen. 2- No adjuvant tamoxifen.3- $\geq 0.05 \mathrm{fmol} / \mu \mathrm{g}$ DNA.4- $<0.05 \mathrm{fmol} / \mu \mathrm{g}$ DNA

5 -in original cohort ER status was not performed by IHC. 
Table 2; Distribution of ER status determined by immunohistochemistry with different percentage of stained cells in relation to cytosol assays

\begin{tabular}{crrr}
\hline & ER fmol/ $\mu \mathrm{g}$ DNA (Cytosol) \\
\hline ER \% (IHC) & $<0.05$ & $\geq 0.05$ & Total \\
\hline 0 & 101 & 36 & 137 \\
$1-9$ & 4 & 3 & 7 \\
$10-24$ & 0 & 6 & 6 \\
$25-49$ & 4 & 18 & 22 \\
$50-74$ & 8 & 77 & 85 \\
$\geq 75$ & 30 & 396 & 426 \\
Total & 147 & 536 & 683 \\
\hline
\end{tabular}


Table 3; time-dependent effect of tamoxifen during the first five years, five to 20 years and all 20 years after start of tamoxifen treatment

\begin{tabular}{|c|c|c|c|c|c|c|}
\hline & $\begin{array}{l}\text { TAM+ vs. TAM- } \\
0-20 \text { years }\end{array}$ & & $\begin{array}{l}\text { TAM+ vs. TAM- } \\
0-5 \text { years }\end{array}$ & & $\begin{array}{l}\text { TAM+ vs. TAM- } \\
5-20 \text { years }\end{array}$ & \\
\hline & $\operatorname{HR}(95 \% \mathrm{CI})$ & $\mathrm{P}$ & $\mathrm{HR}(95 \% \mathrm{CI})$ & $\mathrm{P}$ & $\mathrm{HR}(95 \% \mathrm{CI})$ & $\mathrm{P}$ \\
\hline \multicolumn{7}{|l|}{ Overall survival } \\
\hline $\mathrm{ER}+(\mathrm{IHC} 10 \%)$ & $0.87(0.68-1.11)$ & 0.26 & $0.84(0.45-1.56)$ & 0.58 & $0.87(0.67-1.14)$ & 0.33 \\
\hline ER- (IHC 10\%) & $1.01(0.63-1.62)$ & 0.96 & $0.98(0.45-2.11)$ & 0.95 & $1.04(0.57-1.87)$ & 0.91 \\
\hline ER+ (Cytosol 10\%) & $0.80(0.63-1.02)$ & 0.08 & $0.64(0.35-1.17)$ & 0.15 & $0.84(0.64-1.10)$ & 0.20 \\
\hline ER- (Cytosol 10\%) & $1.33(0.81-2.19)$ & 0.26 & $1.76(0.76-4.06)$ & 0.19 & $1.14(0.61-2.12)$ & 0.68 \\
\hline \multicolumn{7}{|l|}{ Recurrence free survival } \\
\hline $\mathrm{ER}+(\mathrm{IHC} 10 \%)$ & $0.53(0.37-0.74)$ & $<0.001$ & $0.29(0.16-0.53)$ & $<0.001$ & $0.78(0.50-1.22)$ & 0.28 \\
\hline ER- (IHC 10\%) & $0.75(0.44-1.29)$ & 0.30 & $0.61(0.31-1.24)$ & 0.17 & $1.03(0.43-2.48)$ & 0.95 \\
\hline ER+ (Cytosol 10\%) & $0.51(0.37-0.71)$ & $<0.001$ & $0.26(0.15-0.46)$ & $<0.001$ & $0.82(0.53-1.26)$ & 0.36 \\
\hline ER- (Cytosol 10\%) & $0.88(0.48-1.60)$ & 0.68 & $0.96(0.44-2.07)$ & 0.91 & $0.77(0.29-2.03)$ & 0.60 \\
\hline
\end{tabular}



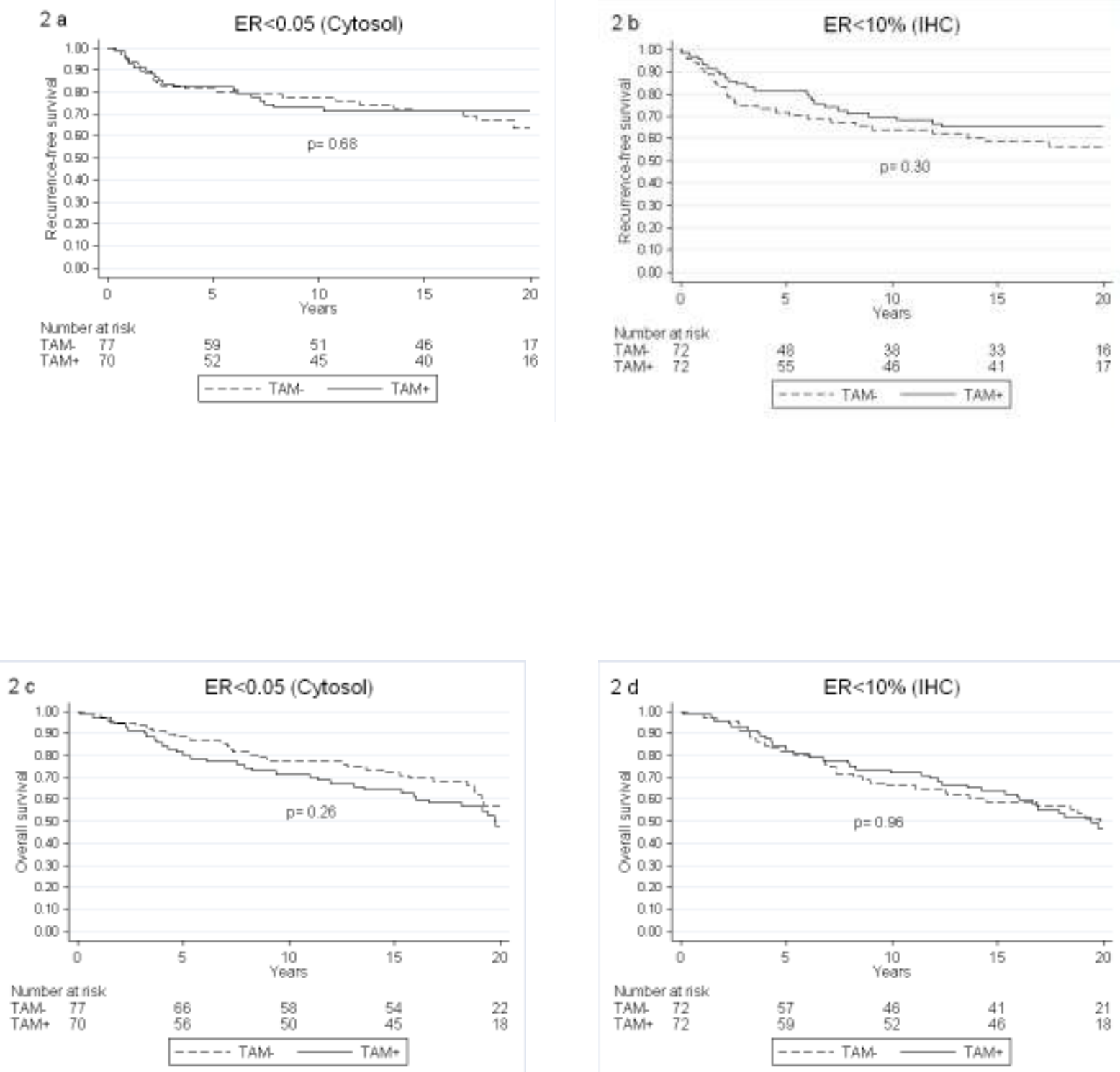

Figure 2; Recurrence-free survival $(\mathrm{a}, \mathrm{b})$ and overall survival $(\mathrm{c}, \mathrm{d})$ of tamoxifen treated and control groups patients with ER negative tumors analysed with cytosol assays and IHC 

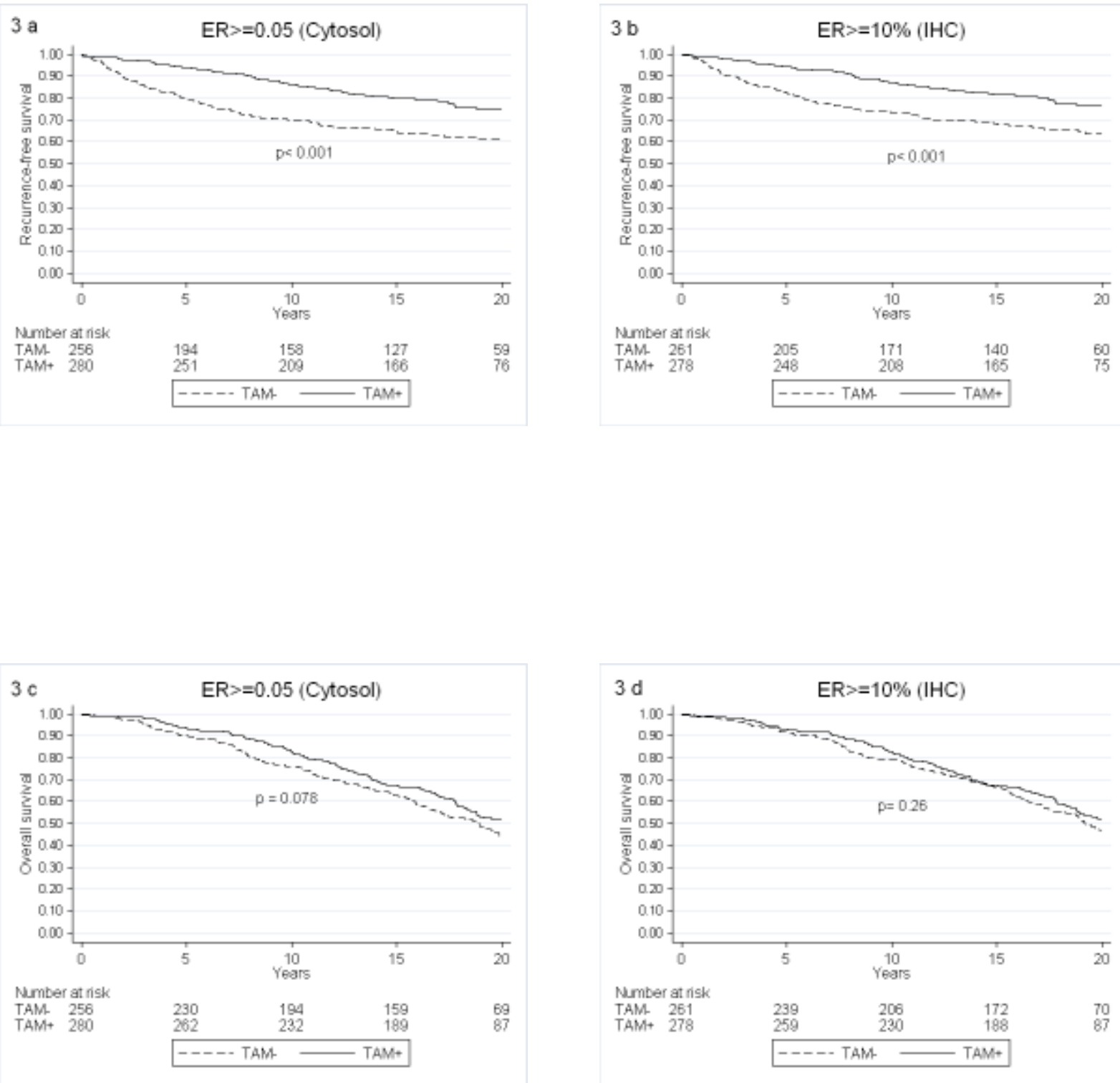

Figure 3; Influence of adjuvant tamoxifen on recurrence-free survival $(a, b)$ and overall survival $(c, d)$ of patients with ER positive tumors analysed with cytosol assays or IHC 

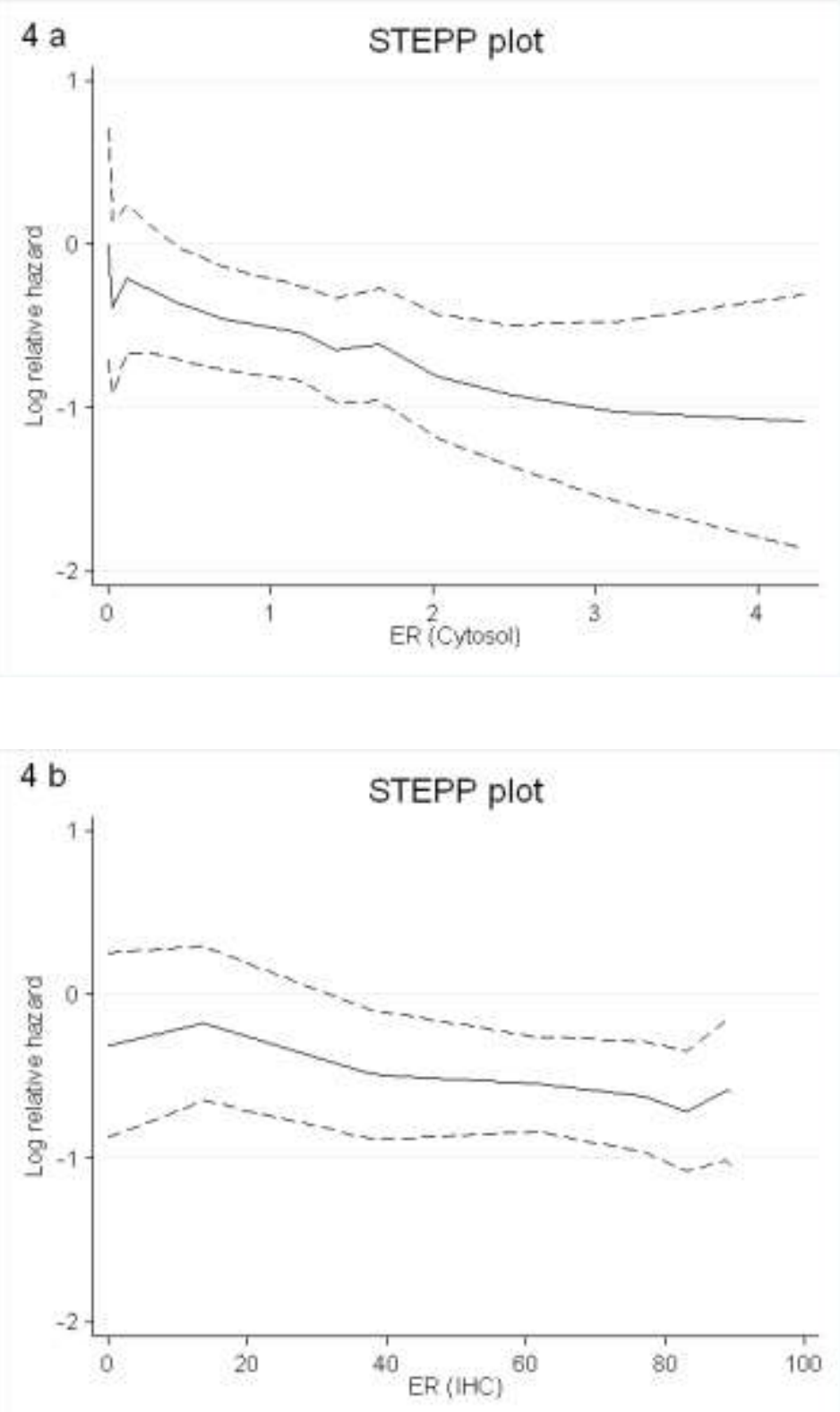

Figure 4; Subpopulation treatment effect pattern plots (STEPP), tailoriented version with $\mathrm{g}=7$, showing the effect of tamoxifen for ER values of cytosol (a) and IHC (b). Log relative hazard for recurrencefree survival with the corresponding 95\% confidence interval (dashed lines) is plotted against the mean ER for each of the thirteen overlapping subgroups. 


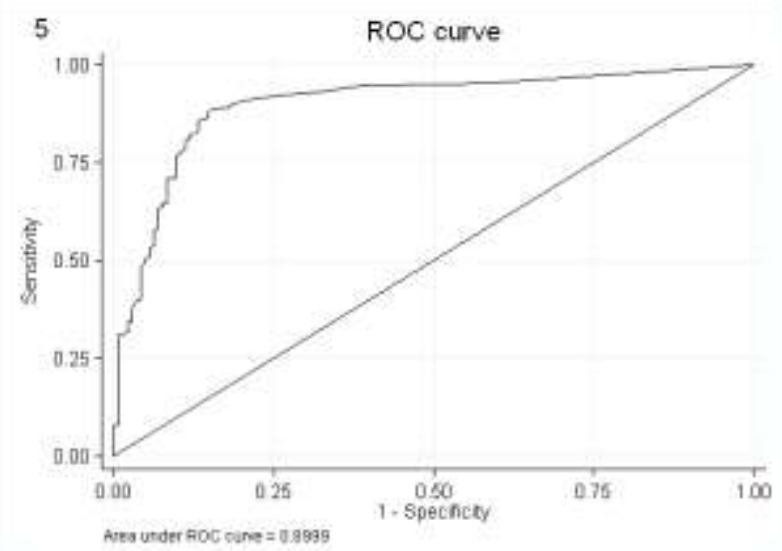

Figure 5a; The ROC curve shows the sensitivity and specificity corresponding to different choices of cut-off for ER cytosol values compared to ER determined by IHC. The cut-off for considering ER to be positive by IHC was set to $10 \%$.

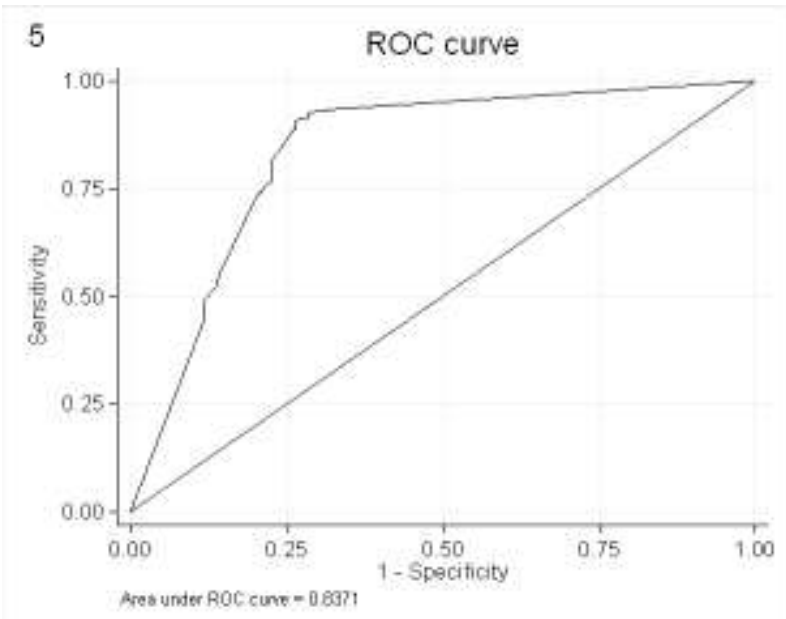

Fig 5b; The ROC curve shows the sensitivity and specificity corresponding to different choices of cut-off for ER determined by IHC compared to ER cytosol values. The cut-off for considering ER to be positive by cytosol was set to $0.05 \mathrm{fmol} / \mu \mathrm{g}$ DNA. 

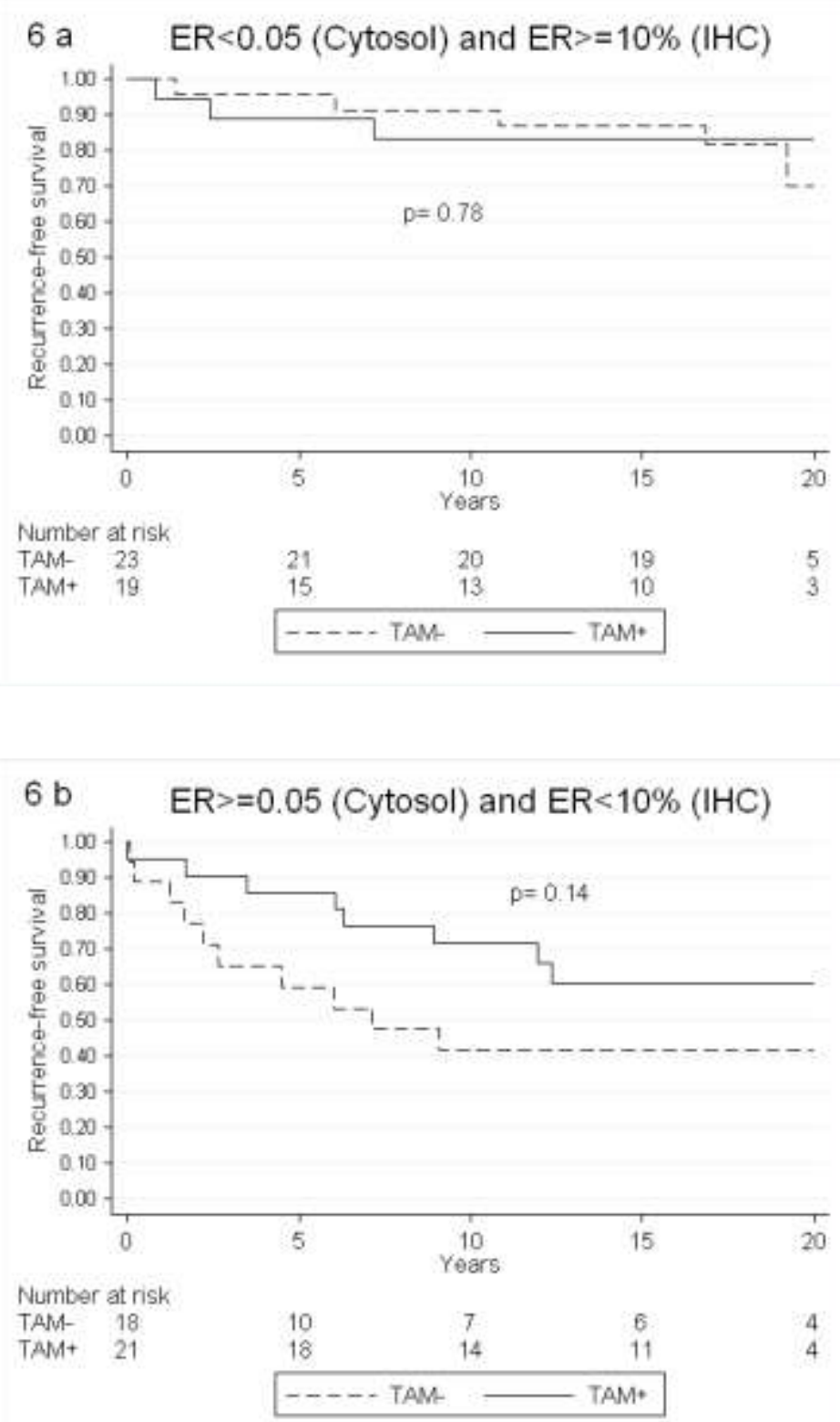

Figure 6, Influence of tamoxifen therapy on recurrence-free survival of patient with $\mathrm{ER}_{\text {cyt-negative/ER }}$ - $\mathrm{HHc}_{\text {-positive (a) and }}$ $\mathrm{ER}_{\text {cy }}$ positive/ER $\mathrm{E}_{\mathrm{IHC}}$-negative (b) 